\title{
Alpha-1 Antitrypsin Deficiency with Severe Pulmonary Emphysema
}

\author{
Akira SAIto, Hajime TakiZAWA, Makoto SAto, Kenji SuZuki, Tadayuki MiYatA, \\ Tatsuyuki TAZAWA*, Toshihiro NUKIWA* and Yutaka MORITA
}

\begin{abstract}
Alpha-1 antitrypsin (AAT) deficiency is a hereditary disorder characterized by an early onset of emphysema. While this disease is common in the Caucasian population, it is quite rare in Japan. To date, only 15 traits have been reported and it can be speculated that many cases of this genetic deficiency may have been overlooked. We report an additional case of AAT deficiency with severe emphysema that is genetically determined as $S_{\text {iiyama }}$ variant by allele-specific polymerase chain reaction (PCR) analysis.
\end{abstract}

(Internal Medicine 43: 223-226, 2004)

Key words: gene analysis, $S_{\text {iiyama }}$ variant, polymerase chain reaction, bronchial asthma

\section{Introduction}

Alpha-1 antitrypsin (AAT) deficiency is a hereditary disorder of an autosomal recessive type first documented in 1963 (1). This disease is characterized by an early onset of pulmonary emphysema with occasional liver damage. Recently the population of AAT deficiency allele combination has been estimated as 3.4 million worldwide (2). Although AAT deficiency is one of the most common hereditary disorders among Caucasians, to date only 15 traits have been reported in Japan. Here we report an additional case of AAT deficiency with severe pulmonary emphysema.

\section{Case Report}

A 45-year-old Japanese man was admitted to our hospital complaining of worsening dyspnea on exertion of over 10 years. On admission his dyspnea was grade 3 of FletcherHugh-Jone's scale. He had a past history of bronchial asthma in his childhood. He was a 35 pack-year smoker. He had no history of exposure to noxious gas. On physical examination wheeze was auscultated on both lung fields. Laboratory tests showed leukocytosis $(10,800 / \mu \mathrm{l})$, eosinophilia $(540 / \mu \mathrm{l})$, elevated serum C-reactive protein $(2.0 \mathrm{mg} / \mathrm{dl})$ and high $\mathrm{IgE}$ level $(200 \mathrm{IU} / l)$. Liver function test was normal. Arterial blood gas showed hypoxemia with mild hypercapnea $\left(\mathrm{PaO}_{2}\right.$ 61 Torr, $\mathrm{PaCO}_{2} 46$ Torr). Chest X-ray showed marked hyperinflation with flattened diaphragm and diffusely decreased vascular markings. Computed tomography of the thorax indicated low attenuation areas throughout both lungs with multiple bullae (Fig. 1). Taking these findings together, we first diagnosed this case as acute exacerbation of pulmonary emphysema with an asthmatic component that was induced by respiratory infection. Corticosteroid, antibiotics and theophylline were intraveneously administered. He started the use of inhaled beclomethasone and anticholinergic agent. Oxygen therapy resulted in improvement of blood gas analysis. His general condition recovered over a few weeks. On recovering from acute exacerbation, pulmonary function test was performed. Forced expiratory volume in one second $\left(\mathrm{FEV}_{1.0}\right)$ was $0.57 l$ and vital capacity (VC) was moderately decreased to $2.41 \mathrm{l}$. On the other hand, residual volume was increased to $4.2 l$. Measurement of diffusion capacity for carbon monoxide (DLco) was impossible. Inhaled beta-agonist failed to improve his $\mathrm{FEV}_{1.0}$. These results were consistent with severe emphysema noted in radiologic findings.

Considering the early progression of emphysema, we suspected of alpha-1 antitrypsin (AAT) deficiency. His serum AAT level was quantified by nephrometric method, and turned out to be quite low $(27 \mathrm{mg} / \mathrm{dl}$ : normal range 166280 ). His family history was investigated and it was revealed that his father had pulmonary emphysema with moderately decreased serum AAT level ( $93 \mathrm{mg} / \mathrm{dl})$, but his genotype was

From Department of Respiratory Medicine, Graduate School of Medicine, University of Tokyo, Tokyo and *Department of Respiratory Oncology and Molecular Medicine, Institute of Development, Aging and Cancer, Tohoku University, Sendai

Received for publication January 20, 2003; Accepted for publication September 27, 2003

Reprint requests should be addressed to Dr. Akira Saito, the Department of Respiratory Medicine, Graduate School of Medicine, University of Tokyo, 7-3-1 Hongo, Bunkyo-ku, Tokyo 113-8655 


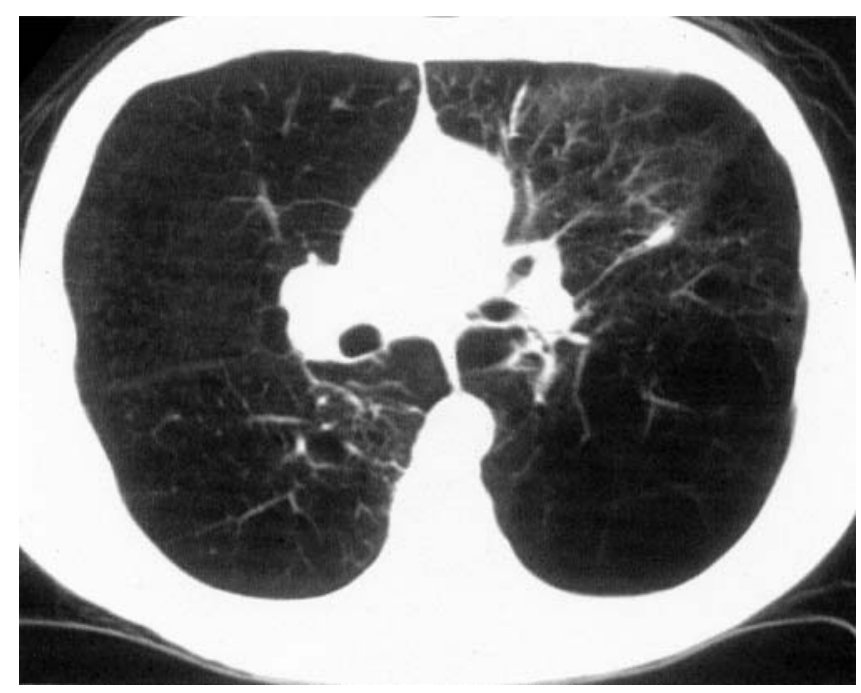

Figure 1. Computed tomography of the thorax. Marked low attenuation areas with multiple bullae were observed.

not characterized. Inbreeding was not found. Gene analysis was performed by allele-specific polymerase chain reaction (PCR) as reported previously (3). Since an accumulation of mutation called $S_{\text {iiyama, }}$, less frequently $\mathbf{M}_{\text {matton }}$ and $\mathbf{M}_{\text {nichinan }}$ had been reported in the Japanese population, we prepared the following allele-specific primers for the detection of these mutations. $5^{\prime}$ primer for the detection of normal allele of $\mathrm{M}_{\text {nichinan }}$ : 5'-AGCCTTCACTGTCAACTTCG-3'; for $\mathrm{M}_{\text {malton }}$ : 5'-AACAGCACCAATATCTTCTT-3'; for deficient allele of $S_{\text {iyymama }}$ : 5'-AGCACCAATATCTTCTT-3' and for the normal allele of $S_{\text {iiyama }}$ : 5'-AGCACCAATATCTTCTTCTT-3'. We used a common 3' primer: 5'-GTTCTGCAGAGCGTCAGTAG-3'. The genomic DNA was extracted from the peripheral blood leukocytes as reported previously (4) and was subject to PCR assay. Amplification was performed for 35 cycles of denaturation $\left(94^{\circ} \mathrm{C}, 1\right.$ minute), annealing $\left(55^{\circ} \mathrm{C}, 2\right.$ minutes) and extension $\left(72^{\circ} \mathrm{C}, 2\right.$ minutes $)$ using a thermal cycler (Perkin-Elmer-Cetus). After completion of the reaction, the reaction mixture was electrophoresed in $2 \%$ agarose gel and stained with ethidium bromide. The reactions could yield a DNA fragment from the allele-specific PCR, if the template DNA and the primers used were complementary. Although predicted sizes of DNA bands were observed for the normal alleles of $\mathbf{M}_{\text {nichinan }}$ and $\mathrm{M}_{\text {matton }}(379$ and $666 \mathrm{bp}$, respectively), the normal allele primer for $S_{\text {iiyama }}$ failed to yield a DNA band (predicted size: $663 \mathrm{bp}$ ). On the other hand, the deficient allele primer yielded one and we concluded that this case was $S_{\text {iyama }}$ variant of ATT deficiency (Fig. 2).

Smoking cessation was successfully achieved and home oxygen therapy was indicated. Though augmentation therapy for deficient AAT was suggested, we finally reached an agreement that he would be observed on an outpatient basis without augmentation therapy.

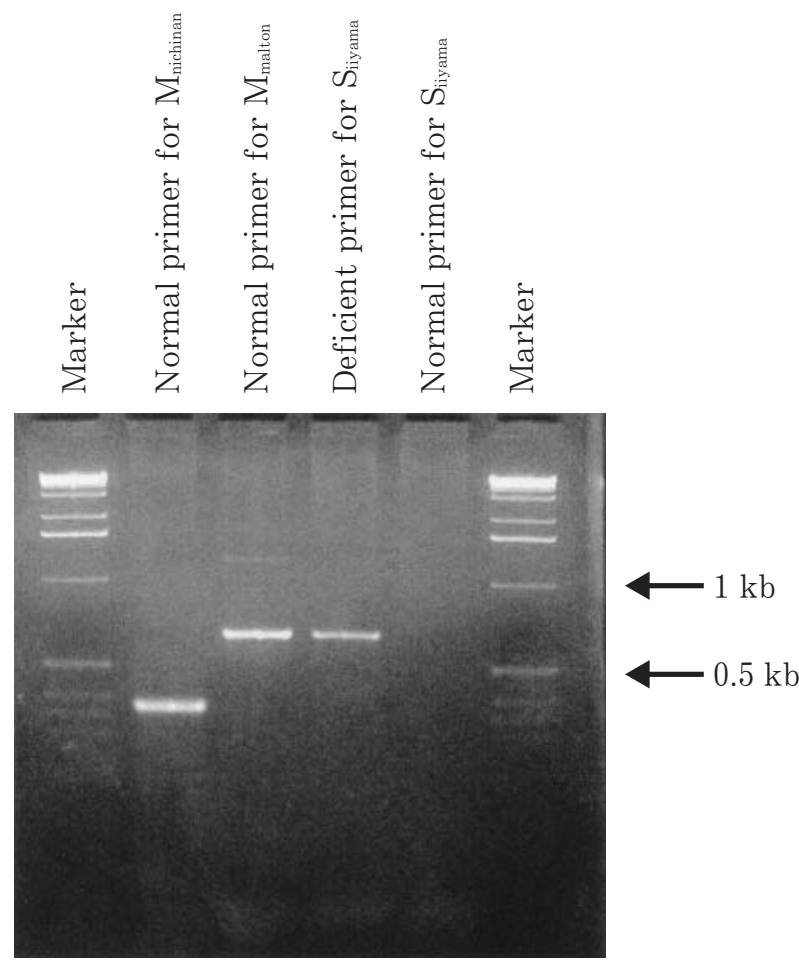

Figure 2. The allele-specific PCR analysis. Although predicted sizes of DNA bands were observed for the normal alleles of $\mathbf{M}_{\text {nichinan }}$ and $\mathbf{M}_{\text {matton}}$, the normal allele primer for $S_{\text {iiyama }}$ failed to yield a DNA band. On the other hand, deficient allele primer yielded a DNA band suggesting that this case was $S_{\text {iiyama }}$ variant of ATT deficiency.

\section{Discussion}

AAT deficiency is an autosomal recessive disorder common among Caucasians. To date, over 20 AAT allele variants have been reported in association with AAT deficiency. AAT normally protects lung tissues from proteolytic action of neutrophil elastase, and lack of this action in the cases of AAT deficiency can result in a high risk for an early onset of pulmonary emphysema. Tobacco smoking can accelerate proteolytic damage of alveolar walls. This mechanism can also be a pathophysiologic model for pulmonary emphysema without AAT deficiency. Bronchial asthma is also associated with this disease as noted in our case (5). In the United States, about $2 \%$ of all pulmonary emphysema has been attributed to AAT deficiency (6). Interestingly, this disease is quite rare in Japan, and we believe this report presents the sixteenth trait found in the Japanese population. All of the reported cases in Japan are listed in Table $1(4,7-15)$. While $\mathrm{ZZ}$ homozygote is the most common cause of AAT deficiency in Caucasians, $S_{\text {iyyma }}$ variant was the primary cause among the Japanese cases of AAT deficiency. In most cases, the diagnosis was made by age $30-40$ years, and serum AAT levels were below $50 \mathrm{mg} / \mathrm{dl}$. Since pulmonary emphysema 
Alpha-1 Antitrypsin Deficiency with Severe Pulmonary Emphysema

Table 1. Reported Cases of AAT Deficiency in Japanese People. The Age Indicated is when Diagnosis of AAT Deficiency was Made

\begin{tabular}{|c|c|c|c|c|c|c|c|}
\hline Trait & Age & Sex & Smoking & AAT level (mg/mdl) & Variant & Pulmonary manifestation & Reference \\
\hline 1 & 38 & M & yes & 14.5 & $S_{\text {iiyama }}$ & $\mathrm{PE}$ & 4 \\
\hline \multirow[t]{3}{*}{2} & 37 & M & $\mathrm{ND}$ & 14.6 & $S_{\text {iiyama }}$ & PE & 4 \\
\hline & 33 & $\mathrm{~F}$ & ND & 17.5 & & none & \\
\hline & 27 & M & yes & 23.4 & & $\mathrm{PE}$ & \\
\hline 3 & 56 & M & yes & 23.5 & $S_{\text {iiyama }}$ & PE & 4 \\
\hline \multirow[t]{2}{*}{4} & 53 & $\mathrm{~F}$ & no & 11.6 & $S_{\text {iiyama }}$ & $\mathrm{BE}$ & 4 \\
\hline & 50 & $\mathrm{~F}$ & no & 30 & & $\mathrm{BE}$ & \\
\hline 5 & 41 & M & yes & 14.9 & $S_{\text {iiyama }}$ & PE & 4 \\
\hline 6 & 35 & $\mathrm{~F}$ & ND & 40 & $S_{\text {iiyama }}$ & PE & 4 \\
\hline 7 & 32 & M & yes & 12 & $S_{\text {iiyama }}$ & PE, BA & 7 \\
\hline \multirow[t]{2}{*}{8} & 33 & M & ND & 18 & $\mathrm{ZZ}$ & none & 8 \\
\hline & 30 & $\mathrm{~F}$ & ND & 20 & & none & \\
\hline 9 & 49 & $\mathrm{~F}$ & no & 70 & $\mathrm{M}_{\text {matton }}$ & PE & 9 \\
\hline 10 & 42 & $\mathrm{~F}$ & yes & 17.9 & $\mathrm{M}_{\text {nichinan }}$ & none & 10 \\
\hline 11 & 52 & M & yes & 19 & SS & PE & 11 \\
\hline 12 & $10 \mathrm{~m}$ & M & no & 104 & $14 q$ syndrome & none & 12 \\
\hline \multirow[t]{2}{*}{13} & 44 & M & yes & not detected & $S_{\text {iiyama }}$ & $\mathrm{PE}$ & 13 \\
\hline & 49 & $\mathrm{~F}$ & no & not detected & & $\mathrm{BE}$ & \\
\hline 14 & 37 & M & yes & 20 & $\mathrm{~S}_{\text {iiyama }}+\mathrm{QO}_{\text {clayton }}$ & $\mathrm{PE}$ & 14 \\
\hline 15 & 35 & $\mathrm{~F}$ & no & 30 & ND & ND & 15 \\
\hline 16 & 45 & M & yes & 27 & $S_{\text {iyyma }}$ & PE & present case \\
\hline
\end{tabular}

PE: pulmonary emphysema, BA: bronchial asthma, BE: bronchiectasis, ND: not described.

associated with AAT deficiency is hard to differentiate from other types, it can be speculated that many cases of AAT deficiency remain undiagnosed. The diagnosis of AAT deficiency should be suspected when patients with pulmonary emphysema have an early onset at ages 30 to 40 . Simply measuring the serum AAT level can be contributable to the diagnosis. Recently AAT augmentation therapy is under investigation and there is accumulating evidence suggesting the efficacy of this therapy (16-18).

\section{References}

1) Laurell C-B, Eriksson S. The electrophoretic alpha1-globulin pattern of serum in alpha1-antitrypsin deficiency. Scand J Clin Lab Invest 15: 132-140, 1963.

2) de Serres FJ. Worldwide racial and ethnic distribution of alpha1antitrypsin deficiency: summary of an analysis of published genetic epidemiologic surveys. Chest 122: 1818-1829, 2002.

3) Okayama H, Curiel DT, Brantly ML, Holmes MD, Crystal RG. Rapid, nonradioactive detection of mutations in the human genome by allelespecific amplification. J Lab Clin Med 114: 105-113, 1989.

4) Seyama K, Nukiwa T, Souma S, Shimizu K, Kira S. Alpha 1antitrypsin-deficient variant $S_{\text {iiyama }}($ Ser53[TCC] to Phe53[TTC]) is prevalent in Japan. Status of alpha 1-antitrypsin deficiency in Japan. Am J Respir Crit Care Med 152 (6 Pt 1): 2119-2126, 1995.

5) Eden E, Mitchell D, Mehlman B, et al. Atopy, asthma, and emphysema in patients with severe alpha-1-antitrypysin deficiency. Am J Respir Crit Care Med 156: 68-74, 1997.

6) Wewers MD, Casolaro MA, Sellers SE, et al. Replacement therapy for alpha 1-antitrypsin deficiency associated with emphysema. N Engl J Med 316: 1055-1062, 1987.
7) Yuasa I, Sugimoto $Y$, Ichinose $M$, et al. $\mathrm{PI}^{*} \mathrm{~S}_{\text {iyymama }}$ A deficiency gene of alpha 1-antitrypsin: evidence for the occurrence in western Japan. Jpn J Hum Genet 38: 185-191, 1993 (in Japanese).

8) Kotsuru M, Tawara T, Harada M. Familial cases of alpha-1 antitrypsin deficiency. Seibutsu-Butsuri-Kagaku 19: 240-241, 1975 (in Japanese).

9) Sakai T, Satoh K, Narumi A, Nagai H, Motomiya M, Kitada O. A case of alpha-1 antitrypsin deficient $\mathrm{M}_{\text {malton. }}$. Jpn J Thorac Soc 29 (Suppl.): 386, 1991 (in Japanese).

10) Matsunaga E, Shiokawa $S$, Nakamura $H$, Maruyama $T$, Tsuda $K$, Fukumaki Y. Molecular analysis of the gene of the alpha-1 antitrypsin deficiency variant, $\mathrm{M}_{\text {nichinan. }}$ Am J Hum Genet 46: 602-612, 1990.

11) Tsuda A, Okuhira M, Haku K, et al. Familial case of alpha-1 antitrypsin deficiency with pulmonary emphysema. Jpn J Med 72: 475476, 1983 (in Japanese).

12) Yamamoto $Y$, Sawa $R$, Okamoto $N$, Matsui A, Yanagisawa $M$, Ikemoto S. Deletion 14q (q24.3 to q32.1) syndrome: significance of peculiar facial appearance in its diagnosis, and deletion mapping of $\mathrm{Pi}$ (alpha 1-antitrypsin). Hum Genet 74: 190-192, 1986.

13) Kadono K, Sakamoto T, Ohtsuka M, et al. Alpha 1-antitrypsin deficiency (Siiyama) with pulmonary emphysema. Nihon Kokyuki Gakkai Zasshi 37: 733-738, 1999 (in Japanese).

14) Miyahara N, Seyama K, Sato T, et al. Compound heterozygosity for alpha-1-antitrypsin (S (iiyama) and QO (clayton)) in an Oriental patient. Intern Med 40: 336-340, 2001.

15) Matsushita H, Shimizu T, Ohshiro A, et al. A trait of alpha-1 antitrypsin deficiency associated with recurrent infections. Nihon Kokyuki Gakkai Zasshi 37 (Suppl.): 255, 1999 (in Japanese).

16) The Alpha-1-Antitrypsin Deficiency Registry Study Group. Survival and FEV1 decline in individuals with severe deficiency of alpha1antitrypsin. Am J Respir Crit Care Med 158: 49-59, 1998.

17) Lieberman J. Augmentation therapy reduces frequency of lung infections in antitrypsin deficiency: a new hypothesis with supporting data. Chest 118: 1480-1485, 2000. 


\section{SAITO et al}

18) Wencker M, Fuhrmann B, Banik N, Konietzko N, Wissenschaftliche Arbeitsgemeinschaft zur Therapie von Lungenerkrankungen. Longitudinal follow-up of patients with alpha (1)-protease inhibitor deficiency before and during therapy with IV alpha (1)-protease inhibitor. Chest 119: 737-744, 2001. 